\title{
Uplift along the western margin of the Deccan Basalt Province: Is there any geomorphometric evidence?
}

\author{
Vishwas S Kale* and Nikhil Shejwalkar \\ Department of Geography, University of Pune, Pune 411 00\%, India. \\ *e-mail: vskale@unipune.ernet.in
}

\begin{abstract}
In line with the passive margin landscape evolutionary model in vogue, sustained erosion and long-distance retreat of the Western Ghat escarpment are widely considered to be the results of erosionally-driven isostatic uplift since Tertiary by many workers. Others have postulated or adduced evidence for strong neotectonic activity in the Ghat region. An obvious question in this regard is whether there is any geomorphometric evidence in support of this widespread view? In order to test the hypothesis of ongoing post-rift fexural uplift or neotectonic activity in the western Deccan Basalt Province (DBP), geomorphometric analysis was carried out and commonly used geomorphic indices of active tectonics (GAT) were derived for 30 selected river basins on both sides of the Western Ghat. SRTM-DEM data and ArcGIS were used to derive the indices. Tectonic geomorphic analysis based on five proxy indicators suggests that the differences in GAT indices, both along strike and across the Western Ghat, are statistically insignificant. The index values are nowhere close to the GAT values typically associated with drainage basins affected by active tectonics and deformation. Mapping of the indices reveals lack of discernable trends. The adduced results indicate that the western DBP belongs to the class of relatively low tectonic activity.
\end{abstract}

\section{Introduction}

The western continental margin of India provides a classic example of an elevated passive margin with a well-defined escarpment, the Western Ghat. This ca. 1-km high and more than 1500-km long megageomorphological feature is considered as the rift shoulder. It is now believed that this great escarpment of India was initiated as a continental edge at the time of the separation of the Seychelles microcontinent following the eruption of the Deccan Trap lavas in late Cretaceous (Widdowson 1997; Subrahmanya 1998; Gunnell and Fleitout 2000; Chand and Subrahmanyam 2003).

As long and continuous erosional escarpments are common along many passive continental margins around the world, denudational unloading and marginal isostatic uplift are commonly assumed to be the fundamental processes responsible for the typical pattern of denudation of escarpments. In line with this landscape evolutionary model, sustained erosion and long-distance retreat of the Western Ghat escarpment are assumed to be the results of erosionally-driven isostatic uplift since Tertiary by many workers (Widdowson 1997; Gunnell 2001). Considering the great height of the Western Ghat scarp, Valdiya (2001) argued that the mega-feature cannot be just ascribed to isostatic uplift, but to neotectonic resurgence.

During the last four decades different researchers have postulated or deduced sustained uplift along the western continental margin of India (Athavale and Anjaneyulu 1972; Kailasam 1975; Powar 1981; Ollier and Powar 1985; Powar 1993; Radhakrishna 1993; Widdowson and Cox 1996; Widdowson 1997; Subrahmanya 1998; Widdowson and Mitchell 1999; Gunnell 2001; Valdiya 2001; Gokarn et al 2003; Mishra et al 2004; Veeraswamy and Raval 2005; Tiwari et al 2006; Catherine et al 2007; Sheth 2007;

Keywords. Geomorphometric analysis; active tectonic indices; uplift; Western Ghat; Konkan rivers; Upland rivers. 
Campanile et al 2008; Mukhopadhyay et al 2008). Based on Bouguer gravity anomalies, Kailasam (1975) identified areas of uplift in Nasik and Sangola; and Power (1981) attributed the typical lineament pattern in DBP to regional uplift. In a recent paper, Leroy et al (2008) have inferred that volcanic margins, such as the western Indian margin, are characterized by $2-3$ times higher uplift since the breakup and rifting than the non-volcanic margins. Furthermore, adjustments in response to denudational isostacy and the resulting activation of faults and fractures has been suggested as the major contributory cause of sporadic seismic activity in the DBP over the past few decades (Mahadevan and Subbarao 1999; Widdowson and Mitchell 1999).

The occurrence of early Tertiary high-level laterites at the present elevation $(>1000 \mathrm{~m}$ ASL) in the Deccan Basalt Province (DBP) is considered as a strong evidence of post-Deccan Trap uplift (Widdowson 1997; Sheth 2007). It has been suggested that the present high-level laterite plateaux (the Mahabaleshwar and the Kas laterite plateaux for instance) are the remains of an extensive lateritic surface that was formed at lower altitude during the early Tertiary. It is hypothesized that this surface was then uplifted to its present-day altitude of up to ca. $1.4 \mathrm{~km}$ above sea level by late Tertiary (Widdowson 1997; Sheth 2007). On the basis of the reconstruction of lateritised palaeosurfaces, Widdowson and Cox (1996) have deduced significant post-Deccan Trap uplift in the Nasik region. They also speculate that this uplift has been responsible for reversal of the primary volcanic dips of the basalt flows in this part of the DBP. In addition, incised meanders and river systems on the Konkan lowland, and knick points and warped terraces along the Upland rivers have been considered as geomorphic markers of recent uplift in the DBP (Widdowson and Mitchell 1999).

An obvious question in this regard is whether there is any geomorphometric evidence to support the widespread view that the western margin of the DBP has experienced significant and protracted uplift from Tertiary to recent times?

Rivers are the most active and sensitive elements of the fluvial landscape. If uplift (tectonic/ isostatic) has occurred in the Neogene and Quaternary times, it should be amply reflected in the drainage basin, valley and network properties of the Deccan Trap rivers heading in the Western Ghat and draining towards the east as well as the west. The main objective of this study, therefore, is to objectively ascertain the tectonic character of the western DBP by deriving and mapping the widely used tectonic activity indices for a number of selected drainage basins on both sides of the Western Ghat.

\section{Methodology}

Geomorphometric characterization of the tectonic properties of a landscape is an extremely complex task. It is well recognized, however, that the commonly-used geomorphic indices of active tectonics (GAT) are powerful reconnaissance tools to evaluate the relationship between tectonics and basin morphology on the regional or basin scale and to identify geologically recent deformation (Bull and McFadden 1977; Keller and Pinter 1996; Burbank and Anderson 2001). These relief, areal, shape and gradient parameters particularly provide useful information about the ongoing tectonics in regions underlined by the same rock-type (Keller and Pinter 1996). Hence, the Deccan Basalt Province is highly suitable for this type of geomorphometric analysis and for making meaningful comparisons between basins and fluvial systems.

Calculations of a number of geomorphometric indices for a large region such as the western DBP was made feasible by the analysis of Digital Elevation Model of ca. 90-m resolution SRTM data. The 90-m SRTM-DEM data have been found to be adequate for regional scale or basin scale morphometric analysis (Harbor and Gunnell 2007; Kale and Shejwalkar 2007). The digital elevation data were used to extract information about drainage basins, network and river profiles. This was achieved by using standard procedures in ArcGIS (Kale and Shejwalkar 2007). We selected 30 rivers and their watersheds on both sides of the regional drainage divide (Western Ghat) in the DBP. The selected rivers include 16 east-flowing rivers (Upland or plateau rivers) and 14 west-flowing rivers (Konkan or coastal rivers). All the selected rivers head in the Western Ghat and fall within the boundary of the Deccan Volcanic Province.

The present study is based on the calculation of five commonly used geomorphic indices of active tectonics (GAT) such as the hypsometric integral (HI), the basin asymmetry factor (AF), the valley width-height ratio (Vf), the stream gradient-length ratio (SL), and the basin elongation ratio (Re). The procedures used to calculate the GAT indices are outlined in table 1. Like all morphometric indices, single values of GAT indices for the entire DBP have very little interpretative value. Therefore, to identify possible tectonic signatures in the western Deccan Basalt Province, the five active tectonic proxies were derived for all the thirty selected rivers. The indices were then assessed and mapped in a GIS application and supported by field observations of the occurrence of knick points, incised meanders, gorges, etc., as markers of active tectonics. In order to understand the spatial distribution of the proxy indicators, index-wise maps have been prepared and presented. In addition to this, 
Table 1. Geomorphic indices of active tectonics (GAT) and their calculations.

\begin{tabular}{|c|c|c|c|c|}
\hline $\begin{array}{l}\text { Sl. } \\
\text { no. }\end{array}$ & Index & Formula & Variables & Reference \\
\hline 1 & $\begin{array}{l}\text { Hypsometric Integral } \\
\text { (HI) }\end{array}$ & $\begin{array}{l}\mathrm{HI}=\left(E_{m}-E_{\min }\right) / \\
\left(E_{\max }-E_{\min }\right)\end{array}$ & $\begin{array}{l}E_{m}=\text { mean elevation } \\
E_{\max }=\text { maximum elevation } \\
E_{\min }=\text { minimum elevation }\end{array}$ & $\begin{array}{l}\text { Bull and } \\
\text { McFadden } \\
(1977)\end{array}$ \\
\hline 2 & $\begin{array}{l}\text { Valley width-height } \\
\text { Ratio (Vf) }\end{array}$ & $\begin{aligned} \mathrm{Vf}= & \mathrm{Vfw} /(((\text { Eld }- \text { Esc }) \\
& +(\text { Erd }- \text { Esc })) / 2)\end{aligned}$ & $\begin{aligned} \mathrm{Vfw}= & \text { width of valley floor } \\
\mathrm{Eld}= & \text { elevation of the left } \\
& \text { valley divide } \\
\text { Erd }= & \text { elevation of the right } \\
& \text { valley divide } \\
\text { Esc }= & \text { elevation of the valley } \\
& \text { floor }\end{aligned}$ & $\begin{array}{l}\text { Bull and } \\
\text { McFadden } \\
\text { (1977) }\end{array}$ \\
\hline 3 & $\begin{array}{l}\text { Asymmetry Factor } \\
(\mathrm{AF})\end{array}$ & $\mathrm{AF}=100\left(A_{r} / A_{t}\right)$ & $\begin{aligned} A_{r}= & \text { area of the basin to the } \\
& \text { right of the trunk stream } \\
A_{T}= & \text { total area of the } \\
& \text { drainage basin }\end{aligned}$ & $\begin{array}{l}\text { Keller and } \\
\text { Pinter (1996) }\end{array}$ \\
\hline 4 & $\begin{array}{l}\text { Stream Length- } \\
\text { Gradient Index (SL) }\end{array}$ & $\begin{array}{l}\mathrm{SL}=(H 1-H 2) / \\
(\ln L 2-\ln L 1)\end{array}$ & $\begin{array}{l}H 1 \text { and } H 2 \text { are the elevations of } \\
\text { each end of a given reach } L 1 \text { and } \\
L 2 \text { are the distances from each } \\
\text { end of the reach to the source }\end{array}$ & Hack (1973) \\
\hline 5 & $\begin{array}{l}\text { Basin elongation } \\
\text { ratio (Re) }\end{array}$ & $\operatorname{Re}=(2 \sqrt{ } A: \sqrt{ } \pi) / L_{B}$ & $\begin{array}{l}A=\text { basin area } \\
L_{B}=\text { length of the basin }\end{array}$ & $\begin{array}{l}\text { Bull and } \\
\text { McFadden } \\
\text { (1977) }\end{array}$ \\
\hline
\end{tabular}

statistical analysis of the GAT indices data were carried out to test the hypothesis that no significant differences exist between the geomorphometric parameters on either side of the Western Ghat as well as within the two major fluvial systems (Konkan and Upland systems).

A word of caution should be added here regarding the longitudinal profiles extracted from the SRTM-DEM data. Because of stepping in adjacent elevations on the SRTM-DEM and the effect of water bodies (dams) the detection of significant breaks and knick zones in the longitudinal profiles is not a very simple and straightforward task, especially for low-gradient reaches. Smoothing of the long profiles using a running mean (aka moving average) of 5 or 11 consecutive elevation values partially reduces the problem but does not eliminate it completely. Therefore, identification of zones of steeper reaches (knick points or zones) could not be achieved. Therefore, the knick points identified in the field or reported in earlier studies have been mapped and discussed.

\section{Results of geomorphometric analysis}

The summary of results of the analysis is presented in table 2, and the spatial variations in the GAT indices are illustrated in figures 1 and 2 . The results of the geomorphometric analysis point to subtle to noteworthy variations in the geomorphic indices both along strike and across the Western Ghat.

\subsection{Hypsometric integral (HI)}

Hypsometric integral is a relief variable that is widely used to measure the degree of fluvial landscape erosion and describes the distribution of elevations across the drainage basin area (Strahler 1952). It is a powerful tool to differentiate between tectonically active and inactive areas (Keller and Pinter 1996). Analysis reveals that the mean integral for the Upland rivers (0.24) is marginally higher than the mean for the Konkan rivers (0.20). Parametric $t$-test indicates that the difference in the means is not statistically significant. All the basins are, more or less equally dissected with reference to their respective base levels, in spite of noteworthy differences in mean and maximum basin elevation (table 2).

Figure 1(A) shows the spatial pattern of the relief parameter. The north Konkan rivers, such as Damanganga, Auranga, Purna, Ambica and Par have relatively higher integral values. Only two Upland rivers, namely, Dudhganga and Burray are characterized by high values of the integral.

\subsection{Valley width-height ratio (Vf)}

Vf is basically an index of the form or shape of the valley cross-section and describes the degree 
Table 2. Summary of the GAT indices for the two major fluvial systems of DBP.

\begin{tabular}{|c|c|c|c|c|c|c|c|c|}
\hline $\begin{array}{l}\text { Fluvial } \\
\text { system }\end{array}$ & Parameter & $\begin{array}{c}\text { Mean } \\
\text { elevation } \\
(\mathrm{m})\end{array}$ & $\begin{array}{l}\text { Maximum } \\
\text { elevation } \\
(\mathrm{m})\end{array}$ & $\mathrm{HI}$ & $\begin{array}{l}\text { BA } \\
(\%)\end{array}$ & Vf & $\mathrm{SL}$ & Re \\
\hline \multirow{4}{*}{$\begin{array}{l}\text { Konkan } \\
(n=14)\end{array}$} & Mean & 223 & 1115 & 0.20 & 57 & 16 & 122 & 0.62 \\
\hline & $\sigma$ & 84 & 173 & 0.07 & 15 & 6 & 35 & 0.13 \\
\hline & Maximum & 367 & 1399 & 0.31 & 84 & 29 & 178 & 0.80 \\
\hline & Minimum & 137 & 811 & 0.10 & 29 & 7 & 66 & 0.41 \\
\hline \multirow{4}{*}{$\begin{array}{l}\text { Upland } \\
(n=16)\end{array}$} & Mean & 635 & 1308 & 0.24 & 58 & 23 & 74 & 0.57 \\
\hline & $\sigma$ & 118 & 233 & 0.06 & 15 & 15 & 18 & 0.06 \\
\hline & Maximum & 786 & 1646 & 0.39 & 78 & 61 & 103 & 0.68 \\
\hline & Minimum & 380 & 777 & 0.14 & 19 & 10 & 48 & 0.46 \\
\hline
\end{tabular}

$\mathrm{HI}=$ hypsometric integral; $\mathrm{BA}=$ basin asymmetry; Vf = valley width-height ratio; $\mathrm{SL}=$ Average stream length-gradient index; $\mathrm{Re}=$ elongation ratio and $\sigma=$ standard deviation.
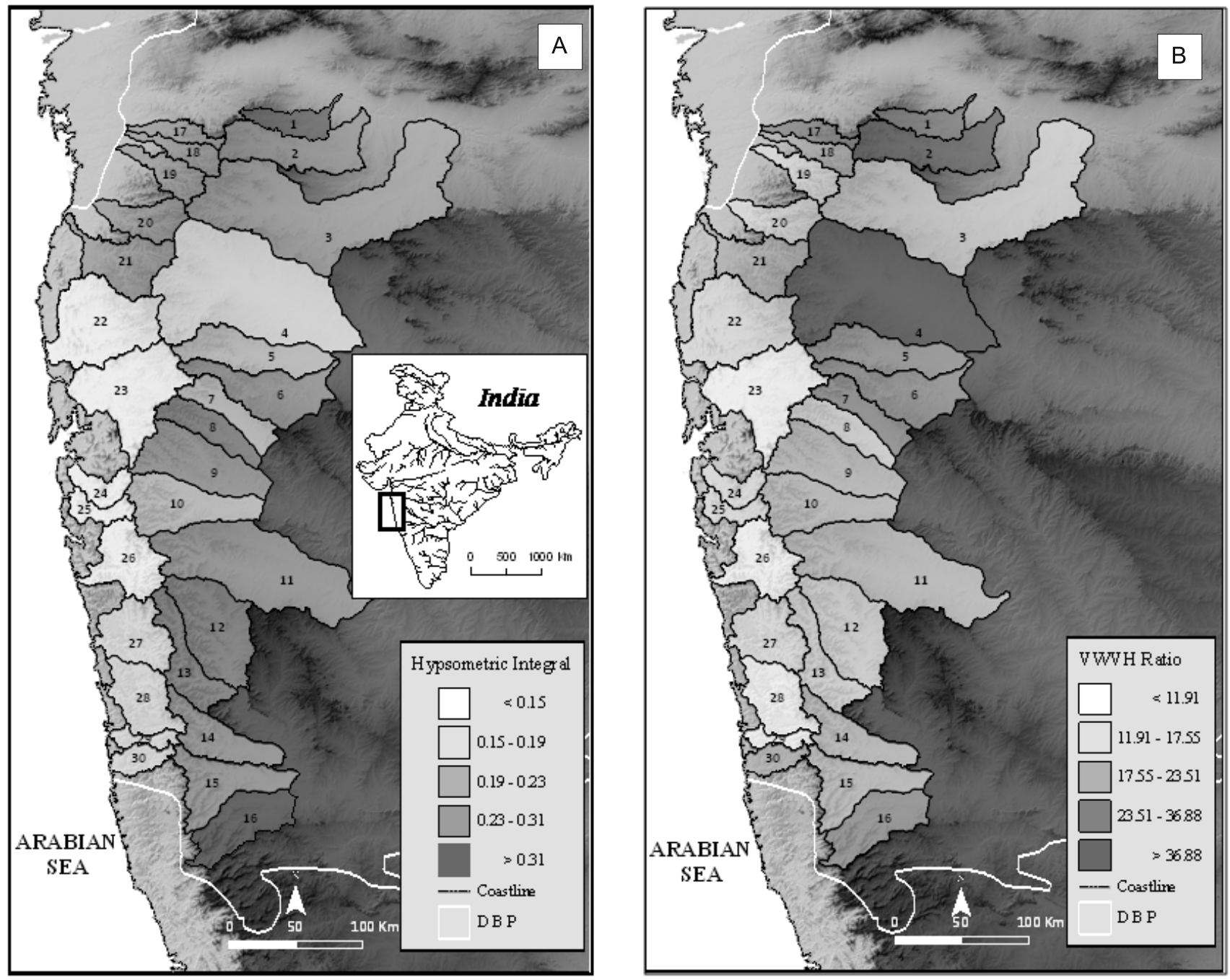

Figure 1. Map showing the spatial pattern of (A) Hypsometric integral (B) Valley width-height ratio (VWVH). Numbers represent drainage basin number. Rivers 1 to 16 are Upland or Plateau rivers, and 17 to 30 are Konkan or coastal rivers. (1) Burray, (2) Panjara, (3) Girna, (4) Godavari, (5) Pravara, (6) Mula (tributary of Pravara), (7) Kukdi, (8) Ghod, (9) Bhima, (10) Mula (tributary of Mutha), (11) Nira, (12) Krishna, (13) Koyna, (14) Varna, (15) Panchganga, (16) Dudhganga, (17) Purna, (18) Auranga, (19) Ambica, (20) Par, (21) Damanganga, (22) Vaitarna, (23) Ulhas, (24) Amba, (25) Kundalika, (26) Savitri, (27) Vasishthi, (28) Shastri, (29) Kajvi, (30) Muchkundi rivers. The inset map shows the location of the study area in India. 

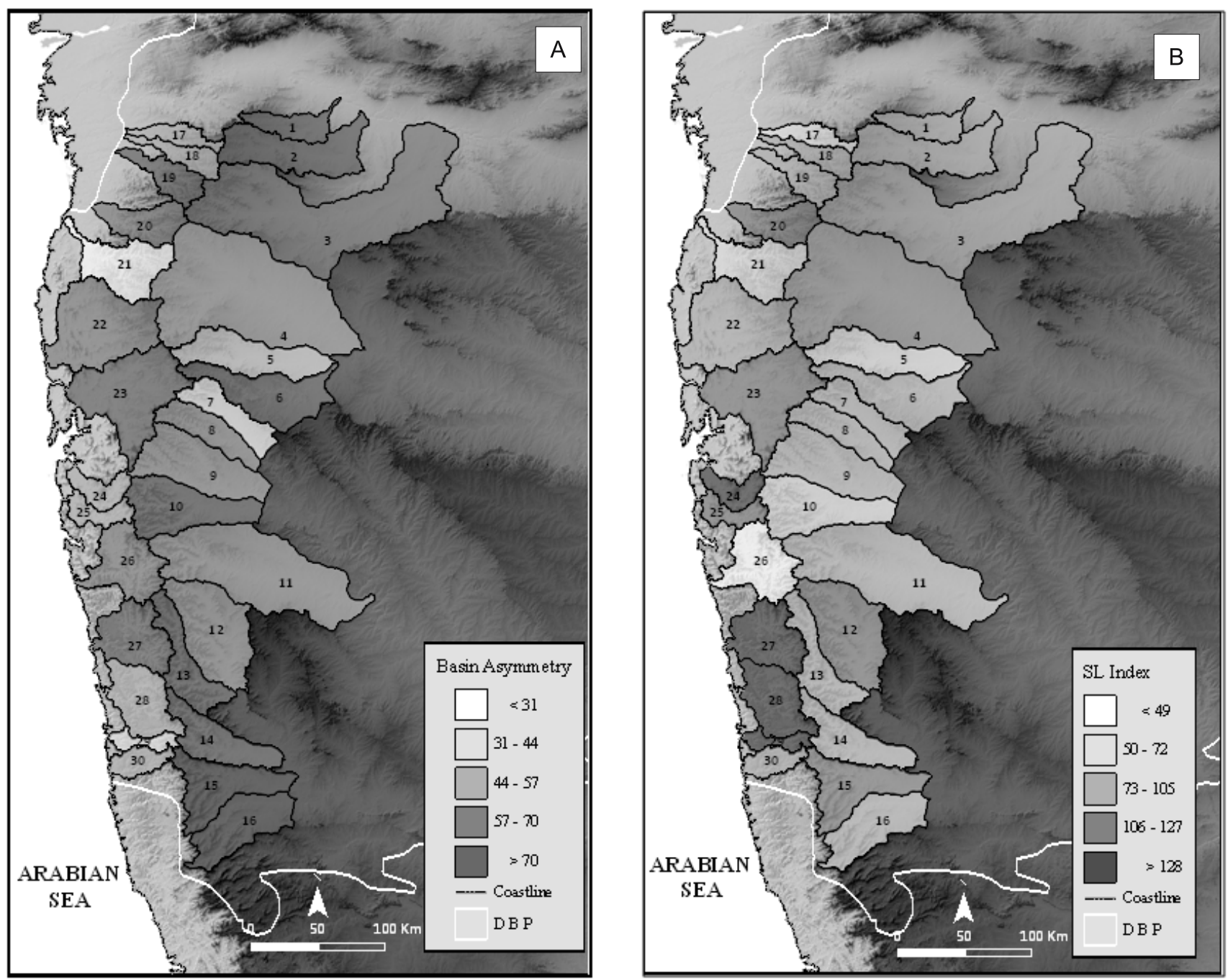

Figure 2. Plots illustrating the spatial pattern in (A) drainage basin asymmetry, and (B) average stream length gradient index. Numbers represent drainage basin number. Rivers 1 to 16 are Upland or Plateau rivers, and 17 to 30 are Konkan or coastal rivers. See figure 1 caption for corresponding names of the rivers.

of maturity of the valley. The Vf ratio is a good measure that indicates whether the river is actively downcutting and incising (Bull and McFadden 1977). The valley profile shape is commonly linked to the rate of uplift in a tectonically active area. The higher the rate of uplift, the more incised the valley cross-section profile. Hence, small values of Vf reflect deep, narrow, V-shaped valleys which are commonly associated with regions of relatively rapid uplift. In contrast, high values are markers of wide, open valleys in regions of minimal uplift rates (Keller and Pinter 1996). In a tectonically stable landscape, valley width increases with time due to lateral migration and erosion.

For each of the selected basins the requisite valley width and height data were obtained along multiple (8-14) valley cross-sections perpendicular to the drainage basin axis, maximum up to $25 \mathrm{~km}$ from the valley head. The average was then taken as the representative of each basin. Figure 1(B) shows that there is no systematic pattern in the distribution of the valley shape parameter. None of the rivers have Vf values less than 1.0 as expected in an area experiencing rapid uplift. In general, the Konkan rivers are relatively narrower than the Upland rivers (table 2). Most of the Upland rivers, particularly Godavari, Panjara and Burray (Vf $=37-61)$ have exceptionally broadfloored valleys. The narrowest valleys are displayed by Krishna, Koyna and Ghod rivers (Vf $=10-11$ ).

Table 2 shows that the mean ratio for Upland rivers is higher than the mean ratio of the Konkan rivers. This clearly indicates that the Upland river valleys are significantly wider than the coastal rivers. Although the difference between the means of the two fluvial systems is statistically insignificant, within the Upland rivers, ANOVA test indicates significant differences (at 0.05 level) in the 
valley shapes. Examination of the data indicates that the southern rivers (Krishna and its tributaries) have relatively narrower valleys (mean $\mathrm{Vf}=15.3)$ than the valleys in Godavari and Tapi basins (mean $\mathrm{Vf}=35.5$ ). The higher $\mathrm{Vf}$ values for most Upland rivers imply predominance of gentle, broad floored, U-shaped valleys of reduced incision.

\subsection{Basin asymmetry factor (AF)}

The influence of tectonics on the drainage pattern is also reflected by the asymmetry of drainage basins (Molin et al 2004). AF is an areal morphometric variable that is used to detect the presence or absence of regional tilt on basin or regional scale (Keller and Pinter 1996). Table 2 shows that not only is there absence of any regionally preferred direction of stream migration, but also that the mean AF values of the Konkan and Upland rivers are not significantly dissimilar (table 2).

Figure 2(A) illustrates that there is no distinct spatial pattern of the distribution of basin asymmetry. The Konkan rivers, such as Savitri, Ambica, Vasishthi and Ulhas have significantly more basin area to the downstream right of the trunk stream $(\mathrm{AF}=68-84 \%)$, whereas the channels of Damanganga and Kajvi ( $\mathrm{AF}=28$ and $39 \%$ respectively) exhibit a shift towards the downstream left side of the basin. In the Upland region, only Kukdi river $(\mathrm{AF}=19 \%)$ has shifted towards the downstream left side of the drainage basin, and Panjara, Burray, Panchganga and Dudhganga $(\mathrm{AF}=71-78 \%)$ have more area to the downstream right of the parent stream. An interesting point is that the southern tributaries of Krishna show some unidirectional asymmetry.

\subsection{Stream gradient-length ratio (SL)}

Hack's (1973) SL index is considered as an excellent measure of the stream power. Variations in the stream gradient index reflect the downstream variations in discharge and stream power, but more commonly the lithologic or tectonic controls on channel slope of a given reach. SL index has been widely used as a proxy to identify areas of anomalous uplift within a landscape.

The average stream length-gradient index value for Konkan rivers is significantly higher than the average SL index of the Upland rivers (table 2). The difference between the means is also statistically significant at 0.05 level. This, of course, is not completely unexpected, given the peculiar geomorphic setting of the Konkan and Upland rivers. Figure 2(B) demonstrates that the southern Konkan rivers such as Shastri, Vasishthi, Kajvi and Savitri have relatively higher average SL index values than the north Konkan rivers such as Purna,
Damanganga and Vaitarna. Within the Upland region, the tributaries of Tapi river have higher SL values.

\subsection{Basin elongation ratio (Re)}

This is an areal morphometric variable that quantitatively describes the planimetric shape of a basin and, thus, indirectly provides information about the degree of maturity of the basin landscape. Bull and McFadden (1977) have shown that basins draining tectonically active areas are more elongated and become more circular with the cessation of uplift. Elongated basin shapes are also associated with high local relief and steep valley slopes (Molin et al 2004).

In the study area, the Re is generally above 0.48 suggesting that all the basins are moderately to highly circular. The mean elongation ratio (0.62) for Konkan basins is higher than the Upland rivers (0.57), implying that the Plateau rivers are more elongated than the Konkan rivers (Kale and Shejwalkar 2007). This in other words means that the coastal river basins are more circular than the Upland basins. However, the difference between the mean values of the two river systems is not statistically significant.

Whereas the Pravara and Burry rivers ( $R e=0.46$ and 0.48 respectively) in the Upland region are most elongated, the Dudhganga and Bhima rivers $(\mathrm{Re}=0.66$ and 0.68 respectively) are more circular. Amongst the Konkan rivers, the Vaitarna, Ulhas, Savitri, Shastri and Amba $(\mathrm{Re}=0.74$ to 0.80$)$ display higher basin circularity than other coastal rivers, particularly Purna and Auranga ( $\operatorname{Re}=0.41$ and 0.43 respectively).

\section{Geomorphometric regionalization and along strike variations}

\subsection{Geomorphometric regionalization}

The rational basis for regionalization of the western DBP is the notion that classification of a landscape on the basis of multiple geomorphometric indices of tectonic activity is always more meaningful than on the basis of a single parameter or index (Keller and Pinter 1996). Therefore, all the five GAT indices were considered and cluster analysis in Matlab was carried out to identify four groups or clusters (figure 3A). The analysis based on Euclidian distance and centroid method reveals that majority of the rivers have, more or less identical geomorphometric characteristics. Within the Konkan basins, the Purna and Muchkundi constitute a distinct group. Over the plateau, two northern rivers, namely Burray and Panjara and three 

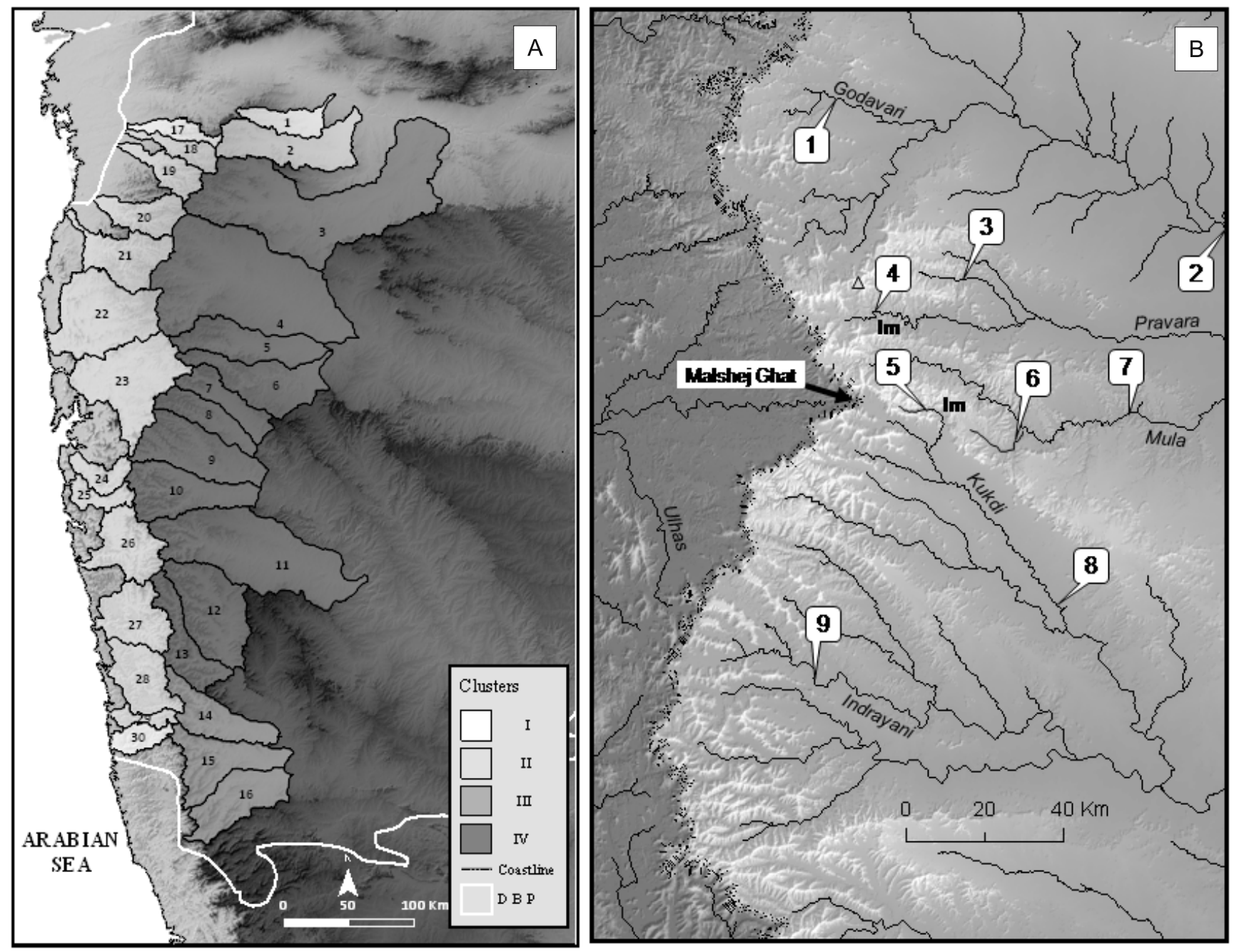

Figure 3. (A) Classification of drainage basins on the basis of cluster analysis. Numbers represent drainage basin number. Rivers 1 to 16 are Upland or Plateau rivers, and 17 to 30 are Konkan or coastal rivers. See figure 1 caption for corresponding names of the rivers. (B) Map showing the approximate location of major knick points on Upland rivers. (1) near Gangapur on Godavari, (2) near Puntamba on Godavari, (3) near Devthan on Adula, (4) at Randha on Pravara, (5) near Chilewadi on Mandvi, (6) near Bote on Kas, (7) near Mandwe on Mula, (8) near Nighoj on Kukdi, (9) at Shelarwadi on Indrayani. $\mathrm{Im}=$ incised meanders. The triangle represents Kalsubai Peak (1646 m ASL). The knick points, identified in the field, have been plotted on the shaded relief map.

southern rivers, namely Varna, Panchganga and Dudhganga show some distinct characteristics in terms of GAT indices (figure 3A). It is important to note that all the outlier basins are located at the northern or the southern extremity of the Deccan Basalt Province.

\subsection{Along strike variations in GAT indices}

Statistical analysis of the data has demonstrated that there are insignificant differences in the GAT indices (except in SL index) between the Konkan and Upland river basins. However, the classification and regionalization (figure $3 \mathrm{~A}$ ) show that there may be some pattern in the indices alongstrike, that is from north to south along the Western Ghat on both sides. In order to ascertain if there is any pattern in the along-strike distribution of GAT indices, the basinwise indices were plotted. Figure 4 illustrates some simple scatter plots for five variables, namely $\mathrm{HI}, \mathrm{AF}$, Vf, SL and Re, along with mean basin elevation for Konkan and Upland rivers.

It can be readily seen from the plots that there is a discernable north-south trend in the GAT indices. The parabolic trend lines (in some cases inverted) indicate greater deviation along the extreme northern and southern margins of the study area. Although the scatter is large, the following general observations can be made regarding the along strike trends (figure 4):

- In case of the Upland rivers the HI, AF, Vf and SL values increase towards the periphery, 

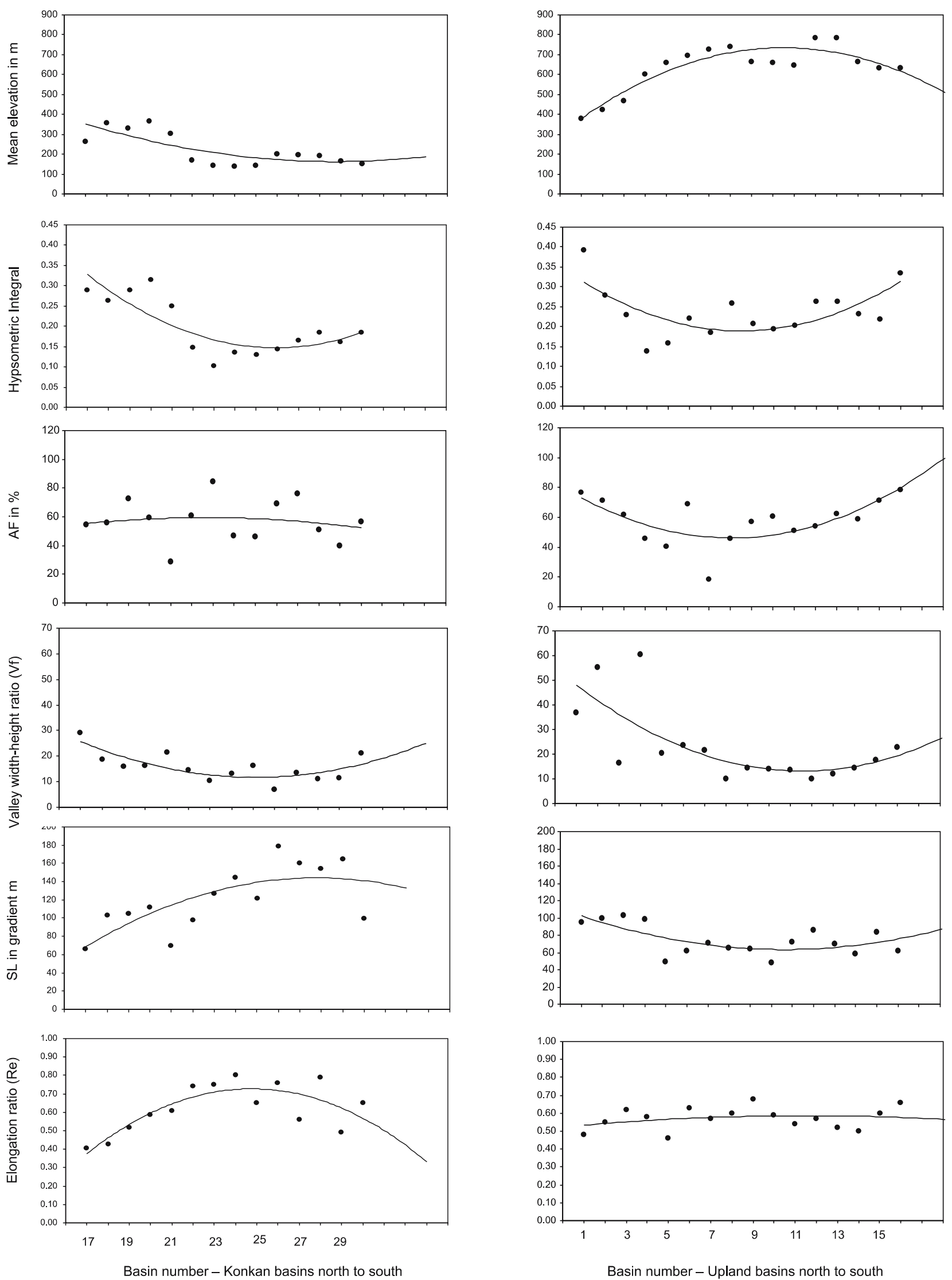

Figure 4. Scatter plot showing along strike variation in the GAT parameters for the Upland (right panel) and Konkan (left panel) rivers. The rivers are plotted from north to south. The continuous lines are trend lines, approximately drawn to understand the nature of variations from north to south. The lines are not regression lines, because basin number ( $X$ variable) is not a real value in the statistical sense, and should be treated as such. 
but the mean elevation decreases. Elongation ratio is, more or less uniform for all the Plateau basins.

- The trend displayed by the Konkan rivers is more complex. The trend lines are more skewed. Basin asymmetry (AF) does not exhibit any trend. The plot shows higher mean elevation, HI and Vf, but lower average SL and Re values for northern basins. The reasons for this pattern are difficult to ascertain, but the presence of Jawahar Plateau, with multi-level benches, in the north and coastal laterite plateaux to the south may have some role to play in these complex trends.

\section{Discussion and conclusions}

\subsection{Interpretation of geomorphic indices of active tectonics}

Studies in tectonic geomorphology have commonly used six geomorphic indices (including mountain front sinuosity, which is not evaluated in this study) as reconnaissance tools to ascertain the level of tectonic uplift in a landscape and identify areas undergoing rapid tectonic uplift.

Synthesis of the results of several previous case studies indicates that landscapes undergoing rapid tectonic uplift should display the following characteristics with respect to GAT indices (Bull and McFadden 1977; Keller and Pinter 1996; Matmon et al 1999; Burbank and Anderson 2001; Silva et al 2003; Molin et al 2004; Peters and Van Balen 2007).

- High hypsometric integral indicating deep incision and rugged relief.

- Asymmetry factor significantly greater or less than 50 suggesting tectonic tilt.

- Anomalously high SL index values in regions underlain by uniform lithology.

- Low values of Vf $(<1)$ reflecting very deep, narrow $\mathrm{V}$-shaped valleys occupied by actively incising streams.

- Very low elongation ratio for tectonically disturbed rivers.

Even a cursory examination of the summary presented in table 2 and the GAT indices maps illustrated in figures 1 and 2 would reveal that the landscape of the western Deccan Basalt Province does not show any of the known typical geomorphometric characteristics of an area undergoing uplift and deformation. One can also note the near-complete absence of any discernable trends in hypsometric integral, basin asymmetry, stream gradient index, valley form and elongation ratio. Further, although the results reveal subtle to noteworthy variability in tectonic geomorphic indices both along strike and across the Western Ghat, the differences (except for average SL index) are not statistically significant.

The highest value of hypsometric integral in the selected drainage basins is 0.39 (table 2) indicating prevalence of mature or subdued topography. Likewise, the river valleys are remarkably wide and open, with Vf ranging between 7 and 61 . These values demonstrate absence of rapid valley downcutting and incision. There is also complete absence of any regional pattern in the occurrence of basin asymmetry. The distribution of basin area with reference to the trunk stream appears to be random and not related to any regional determinant factor. Similarly, the minimum elongation ratio is 0.41 , suggesting that all the basins are not highly elongated, as expected in an uplift-dominated region. If one strictly follows Bull and McFadden's (1977) interpretation of the elongation values, then one has to conclude that higher mean elongation ratio (0.62) of the Konkan basins implies that the uplift has almost ceased in the coastal region. Thus, in view of the facts adduced in this study, it can be stated that the western DBP area belongs to the class of low tectonic activity.

Another point that emerged in the present study is that southern DBP rivers, namely Varna, Panchganga and Dudhganga display some distinct basin characteristics in terms of GAT indices. These southern tributaries of Krishna show some unidirectional basin asymmetry. These rivers have more area to their downstream right indicating a tendency to migrate northward. This tendency is perhaps the manifestation of the influence of the well-established, low-angle northerly dip of basalt flows in the extreme southern part of the DBP (GSI 1976; Subbarao et al 1994). The tributaries of Tapi in the north also show a similar tendency (figure 2A) perhaps because these rivers are under the influence of the SONATA rift related system (Ravi Shankar 1991).

\subsection{Interpretation of supporting field evidences}

One geomorphic fact that is very evident in the field even to a novice is that the river valleys of the Upland are remarkably wide, even on the edge of the Western Ghat Escarpment. Their box-shaped or U-shaped appearance often gives the impression of their being glacial in origin, which of course, is not plausible even remotely. The point is that for the development of such wide, flat-floored valleys $(\mathrm{Vf}=7-61)$ it is of utmost importance that the regional base level remains undisturbed for a lengthy period. If the DBP was experiencing continuous and protracted uplift during Neogene and 
Quaternary, as postulated by many workers, formation of such large, box-shaped valleys is absolutely unlikely. Therefore, unless there is an alternative explanation, it is reasonable to suggest that a vast period of tectonic stability is indicated by the Upland valleys.

One of the alternative explanations is that phreatic processes, rather than fluvial processes, have played an important role in the formation of the DBP valleys. Due to the nearly horizontal nature of the lava flows, the lava pile in the DBP displays a layer-cake structure (Gunnell 2001). In such settings, groundwater sapping is recognized as one of the effective geomorphic processes in the recession of valley-walls. Such sapping valleys exhibit very distinct valley planforms. Sapping valleys are invariably steepwalled and sinuous with a few short tributaries. The valleys are amphitheater-headed and hanging tributary valleys are common (Howard 1995; Lamb et al 2007). Such forms along with little dissection upstream have long been associated with groundwater sapping or seepage erosion (Lamb et al 2008).

Another possible explanation could be that the valley walls have receded by backwasting. If backwasting would have been the dominant process, the planform of the valleys would have revealed broad, shallow re-entrants, separated by sharp cusps, because the attack is areally uniform (Howard 1995).

Examination of the topographical maps and DEM (figure 3B) would clearly indicate that the Deccan Trap valleys do not reveal any similarity with the valleys produced either by groundwater sapping or backwasting. In fact, all the morphologic characteristics suggest that the present-day valleys are the product of normal fluvial erosion. The valley heads are predominately V-shaped in plan (Kale and Subbarao 2004). Here it is pertinent to mention that serious doubts about the role of groundwater sapping or seepage erosion have been expressed even in the case of the amphitheaterheaded valleys of the Colorado Plateau and Hawaii, the so-called classic examples of groundwater sapping in bedrock, because of evidence for flash floods and plunge pool erosion (Lamb et al 2008).

Some workers consider the occurrence of highlevel laterites on the Maharashtra Plateau as one of the key evidences of post-Deccan uplift along the western margin of the DBP (Widdowson 1997; Sheth 2007). Apart from the Western Ghat zone, high-level laterites and bauxites over Deccan basalts also occur at Amarkantak in central India, and at Jath and Bidar along the eastern margin of the DBP. A very fundamental question in this regard is why should the lateritization process cease to operate at higher altitude and why laterites cannot form at higher elevation in tropical areas? It is commonly recognized that laterite formation is favoured by low relief, poor drainage and a warm climate with alternating wet and dry seasons. All these conditions could also occur at a few hundred or a thousand meters above sea level in tropics. Therefore, unless it is proved and established beyond doubt that laterite development is exclusively a low-altitude and/or nearsea level weathering phenomenon, it is hard to accept higher elevation of laterites as a key evidence of substantial uplift. Ollier and Sheth (2008) believe that the high-level laterites, capping the basalt summits, are not the eroded remnants of a once-continuous laterite blanket as hypothesized by Widdowson and Cox (1996), but are valleybottom formations preserved after inversion of relief.

Deeply incised bedrock meanders and a series of knick points at the gorge head occur in the Mandvi and Pravara (and its tributaries Mula-Kas) rivers (Kale and Rajaguru 1988) in the neighbourhood of the Malshej Ghat (figure 3B). Interestingly, the highest peak in the DBP (Kalsubai Peak; $1646 \mathrm{~m} \mathrm{ASL}$ ) and the deepest embayment in the Western Ghat are also observed in the same area (figure 3B). The Pravara river and some of its tributaries are also featured by some of the thickest Quaternary deposits in the DBP. Incised or entrenched meanders and knick points are a common phenomenon in uplifted plateaux around the world and therefore, these features are considered as markers of regional or tectonic uplift (Matmon et al 1999). Whilst, the presence of these spectacular features cannot be contested, one cannot overlook the fact that the valleys immediately north (Godavari and Dharna) and south (Puspavati) are exceptionally wide even by Upland standard (figure 3B), with no sign of deeply incised bedrock channels. The co-existence of such contrasting geomorphic features is intriguing and puzzling. One obvious explanation could be that incised meanders and knick points may not always form by uplift and there may be other reasons for their development. Erosional disequilibrium between river systems has been commonly recognized as one of the causes of knick point formation and upstream migration (Hack 1973). An alternative explanation is that this is perhaps an example of local or block uplift. Here it is pertinent to mention that the southern limit of the bedrock-meander-dominant area coincides with the Kurduwadi or Ghod lineament, a major regional structural feature (Powar and Patil 1980). Needless to say further work is required to improve our understanding of such anomalous geomorphic situations. 

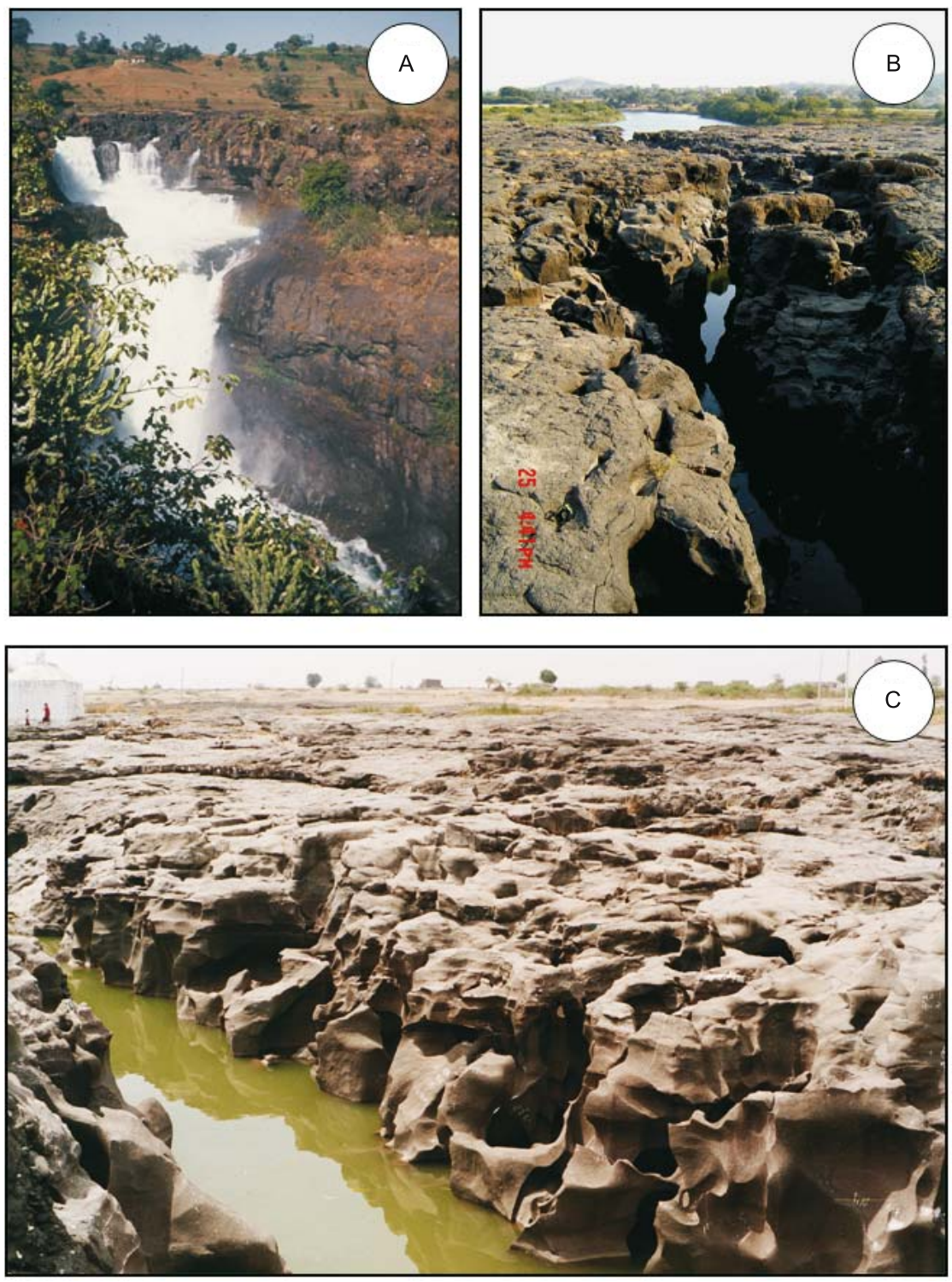

Figure 5. Photographs showing three major knick points in the western Upland region. (A) Randha Falls on the Pravara river (number 4 in figure 3B); (B) Inner channel and scabland area at Shelarwadi on the Indrayani river (number 9 in figure 3B); (C) Inner channel and scabland area near Nighoj on the Kukdi river (number 8 in figure 3B).

Some well-known knick points, with scablands, inner channels, waterfalls and potholes, occur on the Godavari river near Gangapur and Puntamba, on the Pravara river at Randha (figure 5A), on the Mandvi river near Chilewadi, on the Kas river near Bote, on the Mula river near Mandwe, on the Indrayani river at Shelarwadi (figure 5B), on the Kukdi river near Nighoj (figure 5C), and on the Shivaganga river at Baneshwar. Mapping of these knick points does not reveal any spatial pattern, although attitudinally they are, more or less confined to the zone of ca. 580-680 m ASL (Kale and Rajaguru 1988). Because in most cases the waterfalls are associated with gorge-heads, it could be inferred that the knick points are migrating upstream.
Such prominent breaks (figure 3B) in the long profiles have been generally associated with geological or structural control or zones of uplift. However, one fact that is often overlooked while establishing a relation between knick points and faults/lineaments or lithology is that the breaks or knicks rapidly migrate upstream from the point of origin. Therefore, the fundamental cause of knick point formation in most cases may often lie several hundred meters or tens of kilometers downstream and not in the vicinity of the existing inflection point.

Lastly, the conspicuous absence of large-scale depositional features along the west coast of India may be an expression of very modest denudation rates and limited sediment supply along the 
western margin. Given the high relief and high rainfall in the watersheds this is quite surprising. Interestingly, Anderson et al (2005) after scrutiny of solute and sediment load data have inferred that the low total denudation rate along the southern segment of the Western Ghat may reflect lack of strong tectonic activity.

Taken in sum, the interpretation of geomorphic indices of active tectonics derived for 30 rivers on both sides of the Western Ghat, along with other field geomorphic evidences from DBP provide a very modest support to the widespread view that the western margin of India has undergone protracted uplift and tectonic deformation from Tertiary to recent times. However, it is necessary to re-emphasize the fact that the geomorphometric indices, which form the basis of the present study, are only reconnaissance tools that are used to broadly evaluate the relationship between tectonics and basin morphology on the regional scale and to identify areas of active deformation. If the DBP area has indeed undergone significant uplift till recent times, the effects of the tectonic activity have left only subtle imprints on the present-day landscape, which cannot be easily detected by the commonly used geomorphic indices of active tectonics, at least on this spatial scale.

\section{Acknowledgements}

The authors wish to thank an anonymous reviewer and Hetu Sheth for critically reviewing an earlier version of this manuscript and for providing helpful suggestions and comments that significantly improved its content.

\section{References}

Anderson S P, Narayana A, Anderson R S and Molnar P 2005 Dilute rivers and low sediment yields in the Western Ghats Sahyadri: Slow erosion of a steep terrain with high rainfall; American Geophysical Union, Fall Meeting 2005 Abstract \#H53D-0496.

Athavale R N and Anjaneyulu G R 1972 Palaeomagnetic results on the Deccan Trap lavas of the Aurangabad region and their tectonic significance; Tectonophys. 14 87-103.

Bull W and McFadden L 1977 Tectonic geomorphology north and south of the Garlock Fault California; In: Geomorphology in Arid regions (ed.) Doehring D O (Binghamton: State University of New York) 115-138.

Burbank D W and Anderson R S 2001 Tectonic Geomorphology; Blackwell Science.

Campanile D, Nambiar C G, Bishop P, Widdowson M and Brown R 2008 Sedimentation record in the Konkan-Kerala Basin: Implications for the evolution of the Western Ghats and the Western Indian passive margin; Basin Research 20 3-22.
Catherine J K, Gahalaut K and Gahalaut V K 2007 Role of flexure in earthquake triggering along the Western Ghat escarpment India; J. Asian Earth Sci. 31 104-111.

Chand S and Subrahmanyam C 2003 Rifting between India and Madagascar-mechanism and isostacy; Earth Planet. Sci. Lett. 210 317-332.

Gokarn S G, Gupta G, Rao C K and Selvaraj J 2003 Some interesting observations on the tectonics in the Deccan Volcanic Province observed from magnetotelluric studies; Journal of Virtual Explorer 12 55-65.

GSI 1976 Geology of the Kolhapur District Maharashtra, 125th Anniversary Publication, Geological Survey of India.

Gunnell Y 2001 Dynamics and kinematics of rifting and uplift at the western continental margin of India: Insights from geophysical and numerical models; Geol. Soc. India Memoir 47 475-496.

Gunnell Y and Fleitout L 2000 Morphotectonic evolution of the Western Ghats India; In: Geomorphology and Global Tectonics (ed.) Summerfield M (Chichester: John Wiley \& Sons) 321-338.

Hack J 1973 Drainage adjustment in the Appalachians; In: Fluvial Geomorphology (ed.) Morisawa M (London: George Allen and Unwin) 51-69.

Harbor D and Gunnell Y 2007 Along-strike escarpment heterogeneity of the Western Ghats: A synthesis of drainage and topography using digital morphometric tools; J. Geol. Soc. India 70 411-426.

Howard A D 1995 Simulation modeling and statistical classification of escarpment planform; Geomorphology 12 $187-214$

Kailasam L N 1975 Epeirogenic studies in India with reference to vertical movements; Tectonophys. 29 505-521.

Kale V S and Rajaguru S N 1988 Morphology and denudation chronology of the coastal and Upland river basins of western Deccan Trappean landscape India: A collation; Zeitschrift für Geomorphologie 32 311-327.

Kale V S and Shejwalkar N 2007 Western Ghat escarpment Evolution in the Deccan Basalt Province: Geomorphic observations based on DEM analysis; J. Geol. Soc. India $70459-473$.

Kale V S and Subbarao K V 2004 Some observations on the recession of the Western Ghat escarpment in the Deccan Trap region, India: Based on geomorphological evidence; Transactions, Japanese Geomorphological Union 25 231-245.

Keller E A and Pinter N 1996 Active tectonics: Earthquakes Uplift and Landscapes; Prentice Hall, New Jersey.

Lamb M P, Howard A D, Dietrich W E and Perron J T 2007 Formation of amphitheater-headed valleys by waterfall erosion after large-scale slumping on Hawaii; Bull. Geol. Soc. Am. 119 805-822.

Lamb M P, Dietrich W E, Aciego S M, DePaolo D J and Manga M 2008 Formation of Box Canyon, Idaho, by megaflood: Implications for seepage erosion on Earth and Mars; Science 320 1067-1070.

Leroy M, Gueydan F and Dauteuil O 2008 Uplift and strength evolution of passive margins inferred from 2-D conductive modeling; Geophys. J. Int. 172 464-476.

Mahadevan T M and Subbarao K V 1999 Sesmicity of the Deccan Volcanic Province - An evaluation of some endogenous factors; In: Deccan Volcanic Province (ed.) Subbarao K V, Bangalore: Geol. Soc. India Memoir 43 453-484.

Matmon A, Enzel Y, Zilberman E and Heimann 1999 Late Pliocene and Pleistocene reversal of drainage systems in northern Israel: Tectonic implications; Geomorphology $\mathbf{2 8}$ $43-49$. 
Mishra D C, Laxman G and Arora K 2004 Large-wavelength gravity anomalies over the Indian continent: Indicators of lithospheric flexure and uplift and subsidence of Indian Peninsular Shield related to isostasy; Curr. Sci. 86 861-867.

Molin P, Pazzaglia F J and Dramis F 2004 Geomorphic expression of active tectonics in a rapidly-deforming forearc, Sila Massif, Calabria, Southern Italy; Am. J. Sci. $304559-589$.

Mukhopadhyay R, Rajesh M, De S, Chakraborty B and Jauhari P 2008 Structural highs on the western continental slope of India: Implications for regional tectonics; Geomorphology 96 48-61.

Ollier C D and Powar K B 1985 The Western Ghats and the morphotectonics of peninsular India; Zeitschrift für Geomorphologie 54 57-69.

Ollier C D and Sheth H C 2008 The High Deccan duricrusts of India, and their significance for the 'laterite' issue; J. Earth Sys. Sci. 117(5) 537-551.

Peters G and Van Balen R T 2007 Tectonic geomorphology of the northern Upper Rhine Graben Germany; Global and Planetary Change 58 310-334.

Powar K B 1981 Lineament fabric and dyke pattern in the western part of the Deccan Volcanic Province; Geol. Soc. India Memoir 3 45-57.

Powar K B 1993 Geomorphological evolution of Konkan coastal belt and adjoining Sahyadri uplands with reference to Quaternary uplift; Curr. Sci. 64 793-796.

Powar K B and Patil D N 1980 Structural evolution of the Deccan Volcanic Province: A study based on LANDSAT-1 imageries; Proceedings 3rd Indian Geology Congress, Poona 235-253.

Radhakrishna B P 1993 Neogene uplift and geomorphic rejuvenation of the Indian peninsula; Curr. Sci. 64 787-793.

Ravi Shankar 1991 Thermal and crustal structures of SONATA: A zone of mid continental rifiting in the India shield; J. Geol. Soc. India 5 211-220.

Silva P G, Goy J L, Zazo C and Bardají T 2003 Faultgenerated mountain fronts in southeast Spain: Geomorphologic assessment of tectonic and seismic activity; Geomorphplogy 50 203-225.
Sheth H C 2007 Plume-related regional pre-volcanic uplift in the Deccan Traps: Absence of evidence, evidence of absence. In: Plates, Plumes, and Planetary Processes (eds) Foulger G R and Jurdy D M, Geol. Soc. Am. Spec. Pap. 430 785-813.

Strahler A N 1952 Hypsometric (area-altitude) analysis of erosional topography; Bull. Geol. Soc. Am. 63 $1117-1142$.

Subbarao K V, Chandrasekharam D, Navaneethakrishnan P and Hooper P R 1994 Stratigraphy and structure of parts of the central Deccan Basalt Province: Eruptive models; In: Volcanism (ed.) Subbarao K V (New Delhi: Wiley) $217-232$.

Subrahmanya K R 1998 Tectono-Magmatic Evolution of the West Coast of India; Gondwana Res. 1 319-327.

Tiwari P K, Surve G and Mohan G 2006 Crustal constraints on the uplift mechanism of the Western Ghats of India; Geophys. J. Int. 167 1309-1316.

Valdiya K S 2001 Tectonic resurgence of the Mysore plateau and surrounding regions in cratonic southern India; Curr. Sci. 81 1068-1089.

Veeraswamy K and Raval U 2005 Remobilization of the palaeoconvergent corridors hidden under the Deccan trap cover and some major stable continental region earthquakes; Curr. Sci. 89 522-530.

Widdowson M 1997 Tertiary palaeosurfaces of the SW Deccan western India: Implications for passive margin uplift; In: Palaeosurfaces: Recognition reconstruction and palaeoenvironmental interpretation (ed.) Widdowson M, London: Geol. Soc. Spec. Publ. 120 221-248.

Widdowson M and Cox K G 1996 Uplift and erosional history of the Deccan Traps India: Evidence from laterites and drainage patterns of the Western Ghats and Konkan coast; Earth Planet. Sci. Lett. 137 $57-69$.

Widdowson M and Mitchell C 1999 Large-scale stratigraphical, structural, geomorphological constraints for earthquakes in the southern Deccan Traps India: The case for denudationally driven sesmicity; In: Deccan Volcanic Province (ed.) Subbarao K V, Bangalore: Geol. Soc. India Memoir 43 245-274. 